\title{
Elevated cortisol modulates Hsp70 and Hsp90 gene expression and protein in sea bass head kidney and isolated leukocytes
}

\author{
Monica Celi, Mirella Vazzana, Maria Antonietta Sanfratello, Nicolò Parrinello* \\ Laboratory of Marine Immunobiology, Department of Environmental Biology and Biodiversity, Division of Animal Biology and Anthropology, University of Palermo, \\ Via Archirafi 18, Palermo, Italy
}

\section{A R T I C L E I N F O}

\section{Article history:}

Received 18 February 2011

Revised 21 November 2011

Accepted 22 November 2011

Available online 1 December 2011

\section{Keywords:}

Fish

Cortisol

Heat shock proteins

Gene expression

Head kidney

Leukocytes

\begin{abstract}
A B S T R A C T
In fish, interactions between Hsps and cortisol are involved in stress modulated physiological processes including innate immune responses. Cortisol exerts a role in the regulation of Hsps synthesis. Fish head kidney is a lymphomieloid and endocrine organ releasing cortisol, and it is the central organ for immuneendocrine interactions. In sea bass, cortisol intraperitoneal injection and in vitro treatment of head kidney cells show that inducible Hsp70 and Hsp90 are modulated by this hormone. However, an inverse relationship between mRNA expression (real-time PCR) and Hsp70 and Hsp90 protein levels (densitometric band analysis) was found. Time-course assays indicate a cortisol-mediated regulation. Furthermore, Hsp70 gene modulation appears to be more susceptible to the cortisol action and the mRNA was transcribed within $3 \mathrm{~h}$ post-injection. The restoration of the homeostatic conditions was observed at a week p.i., when plasma cortisol baseline was reached. Although fish manipulation and injection exerted stressing effects as indicated by serological parameters, differences between cortisol treated specimens compared to untreated or sham fish are statistically significant. Similar results were found by examining in vitro total cells and isolated leukocytes from head kidney cultured for $3 \mathrm{~h}$ with increasing cortisol concentration. Finally, MTT test and DNA fragmentation experiments showed that the apoptotic effect expected in cortisol-treated cells could be counteracted by high Hsp70 intracellular levels.
\end{abstract}

(c) 2011 Elsevier Inc. All rights reserved.

\section{Introduction}

Exposure of fish to stressing environmental factors gives rise to a series of biochemical and physiological changes mediated by the neuroendocrine system and characterized by increased circulating cortisol [47]. This stress hormone, synthesized by the head kidney interrenal cells, regulates osmolarity, metabolism and modulates immune responses $[25,40,44]$. Injection with exogeneous cortisol mimics stress effects including cortisol-modulated responses such as enhanced serum levels of glucose, lactate and osmolarity $[3,42]$, challenging a differential gene regulation [35]. Following cortisol binding, intracellular glucocorticoid receptors (GR) can exert their activity on the expression of the target genes by ligand-dependent transcription factor [33].

Heat shock proteins (Hsps) are key components in modulating stress responses [35]. They are highly conserved molecular chaperones, ubiquitously expressed, belonging to distinct multigenic families and, according to their molecular size, have been classified into several major categories e.g., Hsp100, Hsp90, Hsp70, Hsp60, Hsp40 and small Hsp. In fish, like in mammals, the Hsp90 and Hsp70 have been related to cytoprotection, cell survival and im-

\footnotetext{
* Corresponding author. Fax: +39 09123860855.

E-mail address: nicolo.parrinello@unipa.it (N. Parrinello).
}

mune responses [16,5,2] exerting a protective role [19]. Two Hsp90 cytosolic isoforms have been reported: the Hsp90 $\beta$ is constitutive and mainly associated with early embryonic development and several cellular pathways [4], the Hsp90 $\alpha$ is inducible and associated with stress-induced cytoprotection. The Hsp70 constitutive form plays an important chaperoning role in unstressed cells, whereas an inducible form rapidly increases following cellular stress [31,49] and can be found in the cytoplasm as well as in extracellular compartments having a role in the innate immunity [2]. Although the induction of Hsps is a stress response [15,19], contrasting results have been reported on the cortisol-Hsps interplay. In salmonids, exogenous cortisol leads to changes in the expression of the Hsp70 gene [3,35]. Elevated levels of circulating cortisol significantly decrease the Hsp30 in the gill of cutthroat trout [1], as well as the hepatic and gill Hsp70 of rainbow trout [4]. Similarly, elevated cortisol suppresses hepatic and gill Hsp70 expression of the cichlid tilapia [4]. On the contrary, daily injections of cortisol into the silver sea bream do not alter hepatic Hsp70 levels after $24 \mathrm{~h}$ and $48 \mathrm{~h}$ p.i. [12], whereas a chronic stress, accompanied by high levels of plasma cortisol, stimulates rainbow trout hepatocytes to synthesize Hsp70 and 90 [43].

In previous papers we reported that high plasma cortisol levels due to seabass confinement stress [40], and in vitro cortisol treatment of peritoneal cavity leukocytes [44] affect innate immunity 
responses. In the present paper we report on head kidney Hsp70 and 90 modulations in sea bass inoculated with exogeneous cortisol. The in vivo and in vitro experiments disclosed that the hormone causes an inverse relationship between the Hsp70 and Hsp90 mRNA expression and the level of the produced proteins.

\section{Materials and methods}

\subsection{Animals and experimental design}

Fishes (200-250 g) were obtained from ECO-ITTICA (Marsala, TP) fish farm. Three distinct fish groups were arranged in separated $100 \mathrm{~L}$ tanks with continuously flowing aerated sea water $\left(18^{\circ} \mathrm{C}\right)$. Fishes were acclimated at constant environmental conditions for at least 2 weeks, and fed with commercial pellets (Biomar for sea bass).

The fish groups (16 fish per group) were designated as untreated (Untr.), vehicle treated (group I) and cortisol treated (group II). For sampling, fishes were anesthetized with $0.05 \%$ of 3 -aminobenzoic acid ethyl ester (MS-222) in seawater. Intraperitoneal injection of $20 \mathrm{mg}$ hydrocortisone $/ \mathrm{kg}$ body mass in $2.5 \mathrm{ml}$ medium (vehicle: ethanol/1:4 diluted Hanks balanced salt solution, v/v) was given to each individual from group II. Fishes from group I were injected with the vehicle alone while untreated group were used as a baseline control. Four fishes from each group were sampled at $3 \mathrm{~h}$, $24 \mathrm{~h}, 72 \mathrm{~h}$ and 1 week after injection. Fishes were sampled from the same tank, and data were recorded from fishes injected with cortisol compared to those from sham and untreated ones.

After anesthesia ( 5 min with $0.05 \%$ of MS-222 in sea water), blood was withdrawn from the heart into heparinized sterile plastic syringes, then fishes were killed with a lethal dose of $0.1 \%$ MS222 , and head kidney was excised. The plasma was obtained by centrifuging the blood samples at $800 \mathrm{~g}$ for $10 \mathrm{~min}$ at $4{ }^{\circ} \mathrm{C}$. The head kidney was divided in two parts, one half was placed in RNA later (Ambion) for RNA analysis, and the second part was stored at $-80^{\circ} \mathrm{C}$ for protein analysis.

To perform in vitro cortisol treatment, an additional fish group (16 individuals) was acclimated as reported above. Six fishes were sacrificed and head kidney surgically excised, the cell preparation from each organ was divided into two halves, one of the two was subjected to cell separation. Cells (unseparated or separated) from three specimens were used to evaluate the expression, and cells from the other three to evaluate the apoptotic effect (MTT and DNA fragmentation).

All experiments were performed in full compliance with the national rules and guidelines (D.Lgs 116/92 and subsequent amendments) and international European Commission Recommendation guidelines for the accommodation and care of animals used for experimental and other scientific purposes (2007/ 526/EC).

\subsection{Hematological parameters}

Plasma cortisol ( $\mathrm{ng} / \mathrm{ml}$ ) level was estimated using an enzymelinked immunosorbent assay kit according to the manufacturer's instructions (Neogen Corporation, Lansing, MI), and values recorded by a microplate reader $(\lambda=450 \mathrm{~nm}$, Labsystems Unishan I). The glucose and lactate levels were recorded by Accutrend GC kit (Boehringer, Mannheim) and Lactate Dry-Fast kit (Sentinel diagnostics, Italy) respectively. Osmolarity was estimated by an osmometer (Roebling, MESSTECHNIK, Berlin).

\subsection{Tissue homogenate supernatant preparation (THS)}

Tissue samples were crushed in liquid nitrogen, and kept in ice for $1 \mathrm{~h}$ with $1 \mathrm{ml}$ of lysis buffer (RIPA: $0.5 \%$ sodium deoxycholate minimum 97\%; $1 \%$ NP40; $0.1 \%$ SDS with PBS-T $\left(\mathrm{Na}_{2} \mathrm{HPO}_{4} 1 \mathrm{M}\right.$, $\mathrm{NaH}_{2} \mathrm{PO}_{4} 1 \mathrm{M}, \mathrm{NaCl} 1.5 \mathrm{M}, 0.1 \%$ Tween 20) pH 7.5, supplemented with a cocktail of protease inhibitors: $2 \mu \mathrm{g} / \mu \mathrm{l}$ antipain, leupeptin and bestatin, $1 \mu \mathrm{g} / \mu \mathrm{l}$ aprotinin and pepstatin, $1 \mathrm{mM}$ benzamidine, and $0.1 \mathrm{mM}$ AEBSF.

Then the samples were centrifuged at $15,000 \mathrm{~g}$ for $30 \mathrm{~min}$ at $4{ }^{\circ} \mathrm{C}$, supernatants were collected, dialyzed against $50 \mathrm{mM}$ Trizma base (Tris[hydroxymethyl] aminomethane) $\mathrm{pH} 7.5$, and the total protein content was determined by using the method of Bradford [7].

\subsection{Total RNA extraction and CDNA synthesis}

Total RNA was isolated from the tissue by using a RNAqueous ${ }^{\mathrm{TM}}$-Midi Kit purification system (Ambion), $1 \mu \mathrm{g}$ total RNA, reverse-transcribed by the Kit Ready to $\mathrm{Go}^{\mathrm{TM}} \mathrm{T}$-primed first-strand using random primers (Amersham-Pharmacia Biotech, USA).

\subsection{Real-time PCR analysis}

Tissue expression of the Hsp genes (Hsp70 Accession No. AY423555; Hsp90 Accession No. AY395632) was detected by Real-time PCR using the Taqman method.

Primers and hybridization probes were designed using primer express software V.0 and synthesized commercially (Applied Biosystem, Foster City, USA). The Taqman probe sequence contained a 5'-FAM fluorophore and $3^{\prime}$ MGB quencher for target genes (Hsp70, Hsp90) and 5'-VIC fluorophore and 3' MGB quencher for the housekeeping gene (Dicentrarchus labrax actin Accession No. AY148350). Real-time PCR analysis was performed using the Applied Biosystem 7500 real-time PCR system. Tissue or cell expression was performed in a $25 \mu \mathrm{l} \mathrm{PCR}$ containing $2 \mu \mathrm{l}$ cDNA converted from $1 \mu \mathrm{g}$ total RNA, $200 \mathrm{nM}$ Hsp70 probe (ACCATGAAGTC CACTGTG), $800 \mathrm{nM}$ Hsp70 of forward (5'-TGGCCTGGAGTCATA TGCTTT- $3^{\prime}$ ) and reverse primers, (5'-TCTTACCGGCAAGCCTTTC A-3'), or $200 \mathrm{nM}$ Hsp90 probe (AGCTGACCGCACCCT), $600 \mathrm{nM}$ forward (5'-GAAAATTGACATCATCCCCAACA-3') and reverse primers (5'-TGCCGATTCCAGTGTCGAT-3'). Two hundred nM actin probe (ACCACAGCCGAGAGG), $600 \mathrm{nM}$ actin forward (5'-CAGAGCGTGG CTACTCCTTCA- $3^{\prime}$ ) and reverse (5'-TCCTTGATGTCACGCACGAT-3') primers, and $12.5 \mu \mathrm{l}$ of Taqman PCR Master Mix (Applied Biosystem) were added. The 50 cycles of the two steps PCR program consisted of initial polymerase activation for $3 \mathrm{~min}$ at $95{ }^{\circ} \mathrm{C}$ followed by denaturing at $95^{\circ} \mathrm{C}$ for $15 \mathrm{~s}$, and annealing/extension at $60^{\circ} \mathrm{C}$ for $45 \mathrm{~s}$, in which fluorescent signal was detected. For every time point/treatment four individuals were sampled and each cDNA sample was run in triplicate together with negative controls. To obtain sample quantification, the $\mathrm{RQ}=2^{-\Delta \Delta \mathrm{Ct}}$ method was used, and the relative changes in gene expression analyzed as described in the Applied Biosystem Use Bulletin N.2 (P/N 4303859). To validate $\mathrm{Ct}$ calculation, the approximately equal amplification efficiencies of the target and the reference gene were checked. To assess whether amplicons had the same efficiency, a sensitive method was used for checking how $\mathrm{Ct}$ varies with template dilution. Serial dilutions $(1,0.5,0.2,0.1,0.005,0.002,0.001)$ of cDNA were amplified by real-time PCR using the target and the housekeeping gene specific primers and the $\mathrm{Ct}$ i.e., CT(Hsp70 or Hsp90)-CT(Actin) was calculated in 3 replicates for each cDNA dilution. Data were analyzed using the linear regression analysis. The amount of Hsp70 and Hsp90 transcript was normalized with actin. In a previous assay, samples from untreated fishes (at $3 \mathrm{~h}, 24 \mathrm{~h}, 72 \mathrm{~h}$ and 1 week) were analyzed. Since the values recorded did not show any timedepending significant difference, a unique pooled control sample was chosen to perform the analysis. The relative Hsp70 and Hsp90 expression was calculated by dividing the normalized value of Hsp70 and Hsp90 by the normalized value obtained from the 
untreated tissue. Consistent results were recorded and presented in Fig. 2 as averages.

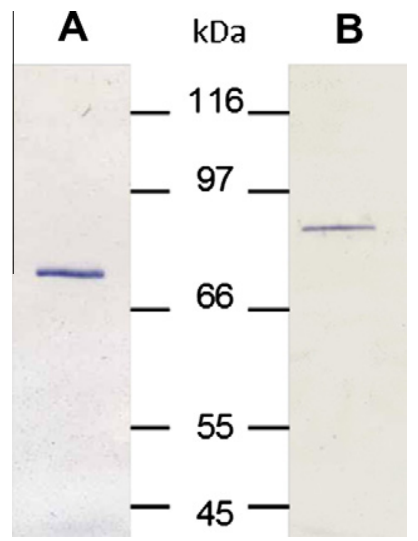

Fig. 1. Cortisol-treated fishes head kidney homogenate supernatant. The identity of the Hsps was analyzed by immunoblotting with a monoclonal anti-Hsp70 antibody (lane A) and a monoclonal anti-Hsp90 antibody (lane B). A high molecular weight marker (Sigma) was used: (from top to bottom: $\beta$-galactosidase from E. coli (116 kDa), phosphorylase b from rabbit muscle (97 kDa), albumin, bovine serum (66 kDa), glutamic dehydrogenase from bovine liver ( $55 \mathrm{kDa})$, ovalbumin from chicken egg (45 kDa).

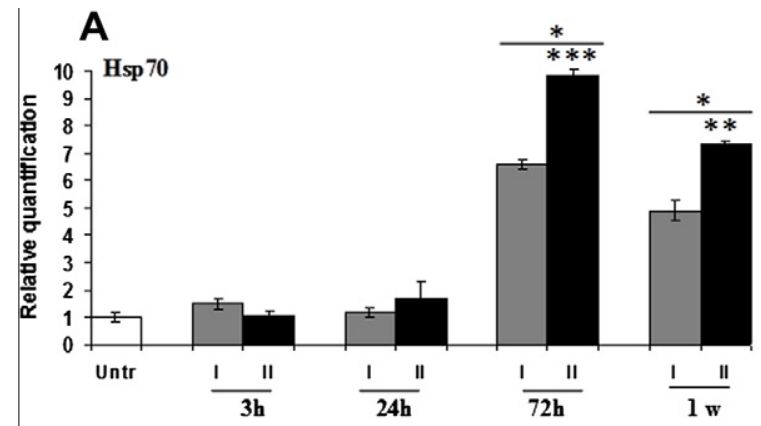

C Hsp70
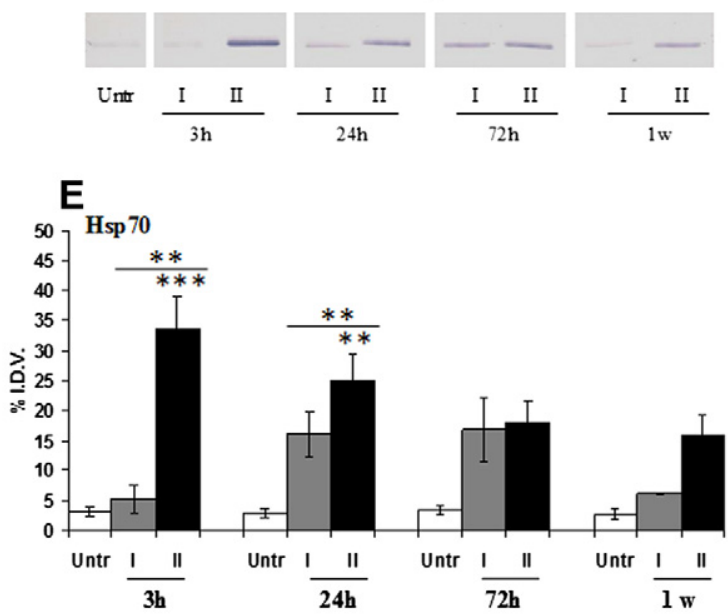

\subsection{SDS-PAGE and Western blot}

The equivalent of $25 \mu \mathrm{g}$ of total lysates for each sample was separated on 7.5\% SDS-PAGE under reducing conditions according to the method of Laemmli [21]. The SDS-polyacrilamide minigels were transferred to a nitrocellulose membrane by using a semidry transfer apparatus (BioRad) and blocked with $5 \%$ bovine serum albumin (BSA) in TBS-T (20 mM Trizma base pH 7.5, $300 \mathrm{mM} \mathrm{NaCl}$, $0.1 \%(\mathrm{v} / \mathrm{v})$ Tween 20 with $0.02 \%$ sodium azide) for $1 \mathrm{~h}$ at room temperature (r.t.). According to previous papers [24,8] commercial antibodies identified fish Hsps as described below. The membranes were incubated overnight with anti-mouse Hsp70 or Hsp90 mAbs (1:3000 dilution, $1 \mathrm{~h}$ at r.t., at $4{ }^{\circ} \mathrm{C}$ ) from Sigma-Aldrich, washed with TBS-T (three times for $5 \mathrm{~min}$ ), incubated with alkaline phosphatase-conjugated goat anti-mouse $\operatorname{IgG}(1: 10,000$ for $1 \mathrm{~h}$ at r.t.). After washing with TBS-T (three times for $5 \mathrm{~min}$ ), the membranes were incubated with 5-bromo-4-chloro-3-indolyl phosphate/nitro blue tetrazolium liquid substrate system (BCIP/NBT). Densitometric analysis of the immunoblotted bands was carried out using AlphaImager software. Four specimens from untreated, I and II fish groups were examined at every time points. Each assay was repeated three times.

\subsection{Separation of head kidney cells (HKCs)}

The head kidney was cut under sterile conditions into small fragments, dissociated using a plastic pestle, and filtered through a cell strainer of $70 \mu \mathrm{m}$ nylon (Falcon). The resulting suspension $\left(120 \times 10^{6}\right.$ cells $\left./ \mathrm{ml}\right)$ was halved. An aliquot $\left(60 \times 10^{6}\right.$ cells $\left./ \mathrm{ml}\right)$
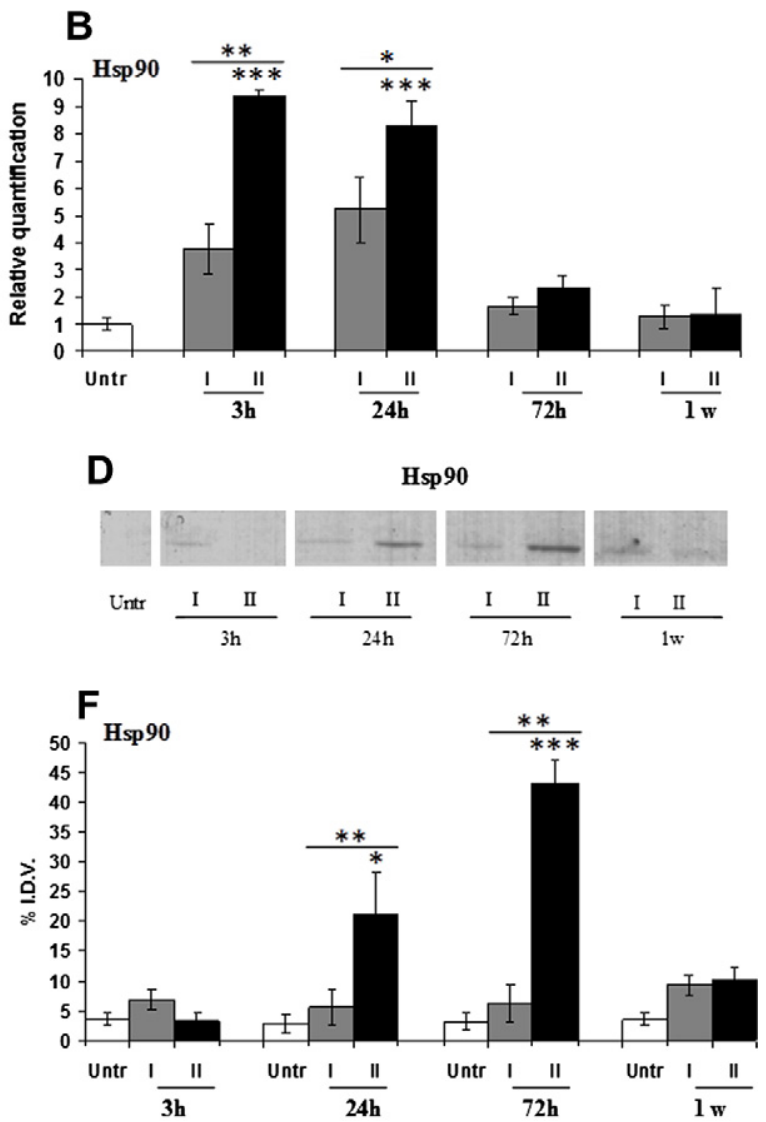

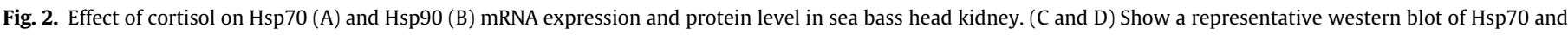

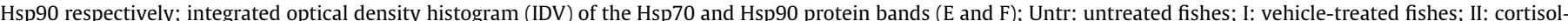

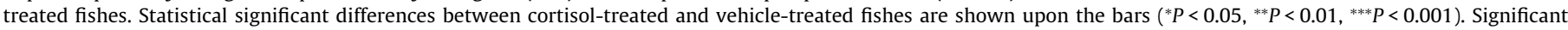
differences between treated fishes (I, II) and untreated specimens are also indicated. 
was layered on a gradient at 34-46\% v/v Percoll/Hanks balanced salt solution (HBSS: $190 \mathrm{mM} \mathrm{NaCl}, \mathrm{KCl} 5.36 \mathrm{mM}, 5.54 \mathrm{mM}$ glucose, $\mathrm{KH}_{2} \mathrm{O}_{4}$ 0:44 mM, $\mathrm{Na}_{2} \mathrm{HPO}_{4} 0.56 \mathrm{mM}$; pH 7.6, $370 \mathrm{mOsm}$ ). The gradient was centrifuged at $400 \mathrm{~g}$ for $25 \mathrm{~min}$ at $4{ }^{\circ} \mathrm{C}$ and the band at the interface between $34 \%$ and $46 \%$ was collected and washed in L15-medium (Leibovitz medium, 100 units penicillin/ml, 100 units streptomycin/ $\mathrm{ml}$ and 10 units heparin/ml, osmolarity adjusted to $370 \mathrm{mOsm})$. An aliquot of $40 \times 10^{6} / \mathrm{ml}$ separated cells was obtained from each organ. Dead cells less than $0.5 \%$ were revealed by the trypan blue $(0.01 \%)$ exclusion test.

\subsection{Treatment in vitro of the head kidney cells with cortisol}

The cells $\left(2.5 \times 10^{6} / \mathrm{ml}\right)$ were incubated with increasing cortisol concentrations at $18{ }^{\circ} \mathrm{C}$ under mild shaking for $3 \mathrm{~h}$. A cortisol stock solution was prepared by dissolving hydrocortisone (Sigma) in absolute ethanol diluted with Hanks balanced salt solution (HBSS). An aliquot was added to the cell suspension to reach $10 \mathrm{ng} / \mathrm{ml}$, $100 \mathrm{ng} / \mathrm{ml}, 1000 \mathrm{ng} / \mathrm{ml}, 10,000 \mathrm{ng} / \mathrm{ml}$ cortisol final concentrations.

The control cells were treated in an equal manner and incubated in a medium containing $0.1 \%$ ethanol, without hydrocortisone. After treatment, cells were washed in HBSS (3 times) at $400 \mathrm{~g}$ for $5 \mathrm{~min}$. The cells suspended in L15 medium were incubated in the dark for $60 \mathrm{~min}$ at $18{ }^{\circ} \mathrm{C}$ [10].

\subsection{MTT assay for cell viability}

The MTT assay was carried out according to the method of Mosmann [27]. Briefly, cells $\left(20 \times 10^{6} / \mathrm{ml}\right)$ were incubated with $5 \mathrm{mg} / \mathrm{ml}$ methylthiazolyldiphenyl-tetrazolium bromide in L15 medium, for $3 \mathrm{~h}$ at $18^{\circ} \mathrm{C}$ and sterilized $(0.2 \mu \mathrm{m}$ filter). Then the microplates were centrifuged for $5 \mathrm{~min}$ at $50 \mathrm{~g}$ at $4{ }^{\circ} \mathrm{C}$, then $100 \mu \mathrm{l}$ of dimethyl sulfoxide (DMSO) was added and the mixture incubated for $10 \mathrm{~min}$ with gentle shakings. Aliquots $(100 \mu \mathrm{l})$ of the resulting sample were transferred in 96-well plates and absorbance $(550 \mathrm{~nm})$ was recorded by a microplate reader (Labsystems Uniskan I).

\subsection{DNA fragmentation assay}

DNA was extracted by using the Sigma-Aldrich geneluite mammalian genomic miniprep kit based on a silica-based membrane, specially selected for genomic DNA purification, in a convenient spin column format. To ensure macromolecule denaturation, a cell suspension $\left(5 \times 10^{6} / \mathrm{ml}\right)$ of total and separated HKCs cortisoltreated and untreated control, was lysed with a chaotropic salt-containing solution to insure the through denaturation of macromolecules. DNA was bound to the spin column membrane, the remaining lysate was removed by centrifugation $(6500 \mathrm{~g})$ and cell debris by a filtration column. After washing, the DNA was eluted with buffer, analyzed through standard $1 \%$ agarose gel electrophoresis and visualized with ethidium bromide $(5 \mu \mathrm{g} / \mathrm{ml})$ reaction.

The DNA fragmentation was analyzed using 1\% agarose gel electrophoresis to check for a "ladder" pattern at 200-BP intervals due to apoptosis or a random DNA fragmentation which forms a "smear" on agarose gels disclosing necrosis.

\subsection{Statistical analysis}

The experiments were performed using 4 specimens for each time point and the results were expressed as a mean value $\pm S D$. The data were compared using the analysis of variance (ANOVA). Homogeneity of variances was performed using Cochran's test prior to the ANOVA analysis. Whenever necessary the data were log-transformed. Posthoc comparisons were made using Student's $t$ test and the significant level was set at $P<0.05$; the analysis was performed with Statistica 6.0 (StatSoft, Tulsa, OK, USA).

\subsection{Chemicals}

Unless otherwise reported all chemicals were from Sigma-Aldrich (Germany).

\section{Results}

\subsection{Serological parameters}

Sham fishes from group I examined at $3 \mathrm{~h}$ and $24 \mathrm{~h}$ post vehicle injection presented a significant increase in endogenous plasma cortisol $(P<0.01 ; P<0.05$ respectively) compared to untreated fishes (Table 1). Following intraperitoneal cortisol injection (fishes from group II), the hormone level was significantly $(P<0.001)$ higher than sham fishes. Such an increase was evident at $3 \mathrm{~h}$ and 24 h p.i. (Table 1 ).

Glucose, lactate and osmolarity levels (Table 1 ) reached the highest levels at $24 \mathrm{~h}(P<0.001 ; P<0.05 ; P<0.001$, respectively $)$.

\subsection{Hsps identification}

Fig. 1 shows the cross reaction of the head kidney Hsp70 (lane A) and 90 (lane B) contained in a homogenate supernatant and assayed with monoclonal antibodies.

\subsection{Hsp70 and Hsp90 mRNA and protein expression levels after cortisol administration}

The expression of Hsp70 mRNA was analyzed by real-time PCR. Fig. $2 \mathrm{~A}$ shows that in the head kidney excised at $3 \mathrm{~h}$ and $24 \mathrm{~h}$ p.i. from sham and cortisol-treated fish (groups I and II), the mRNA

Table 1

Plasma Cortisol, glucose, lactate and osmolality levels of untreated (Untr), vehicle-treated (I) and cortisol-treated (II) sea bass at $3 \mathrm{~h}, 24 \mathrm{~h}, 72 \mathrm{~h}$ and $1 \mathrm{heek}$.

\begin{tabular}{|c|c|c|c|c|c|c|c|c|c|c|c|c|}
\hline \multirow[t]{2}{*}{ Time post stress } & \multicolumn{3}{|l|}{$3 h$} & \multicolumn{3}{|l|}{$24 \mathrm{~h}$} & \multicolumn{3}{|l|}{$72 \mathrm{~h}$} & \multicolumn{3}{|l|}{$1 \mathrm{w}$} \\
\hline & Untr & I & II & Untr & $\mathrm{I}$ & II & Untr & $\mathrm{I}$ & II & Untr & I & II \\
\hline \multicolumn{13}{|c|}{$* *$} \\
\hline Cortisol (ng/ml) & $89 \pm 44$ & $260 \pm 37^{b}$ & $625 \pm 25^{c}$ & $95 \pm 19$ & $300 \pm 70^{\mathrm{a}}$ & $590.6 \pm 22^{c}$ & $86 \pm 21$ & $145 \pm 20$ & $170 \pm 31^{\mathrm{a}}$ & $70 \pm 17$ & $111 \pm 46$ & $116 \pm 37$ \\
\hline Glucose (mg/dl) & $68 \pm 15$ & $126 \pm 21^{b}$ & $121 \pm 2^{\mathrm{b}}$ & $70 \pm 10$ & $95 \pm 11$ & $\begin{array}{l}* * \\
260 \pm 26^{c}\end{array}$ & $75 \pm 19$ & $91 \pm 16$ & $103 \pm 26$ & $71 \pm 5.9$ & $86 \pm 26$ & $90 \pm 15^{b}$ \\
\hline Lactate (mg/dl) & $5.5 \pm 2.1$ & $24 \pm 10$ & $19 \pm 4^{b}$ & $8 \pm 10$ & $16 \pm 5$ & $18 \pm 9^{a}$ & $7 \pm 16$ & $17.8 \pm 4.2$ & $16.4 \pm 3^{a}$ & $4.5 \pm 11$ & $14 \pm 6$ & $27 \pm 6$ \\
\hline Omolarity (mOsm/kg) & $370 \pm 12$ & $374 \pm 13$ & $383 \pm 19^{b}$ & $360 \pm 15$ & $367 \pm 7^{\mathrm{a}}$ & $428 \pm 6^{c}$ & $366 \pm 20$ & $382 \pm 5$ & $400 \pm 16$ & $351 \pm 22$ & $366 \pm 12$ & $366 \pm 20$ \\
\hline
\end{tabular}

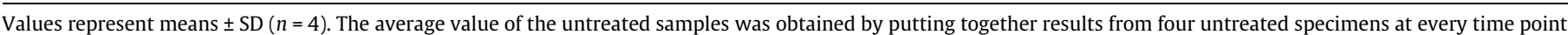

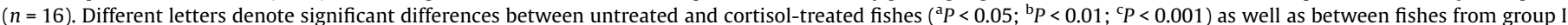
and II $\left({ }^{*} P<0.05,{ }^{* *} P<0.01\right)$ are shown. 
levels did not change significantly. On the contrary, at $72 \mathrm{~h}$ and 1 week p.i., the specimens from group II presented a significant increase in Hsp70 mRNA compared to the untreated $(P<0.001$, $P<0.01$, respectively) and sham fish $(P<0.05)$. In untreated fish a constant level was found. In sham fish (group I) the values were higher than those from untreated ones, i.e., 7 times at $72 \mathrm{~h}$ and 5 times at 1 week. The exogenous cortisol increased the mRNA expression of 10 times at $72 \mathrm{~h}$ and 7 times at 1 week compared to the untreated specimens.

Real-time PCR analysis revealed that the Hsp90 mRNA level was increased both in samples from sham and cortisol-treated fish, as compared to the constant levels found in the untreated specimens (Fig. 2B). In sham fish, at $3 \mathrm{~h}$ and $24 \mathrm{~h}$ p.i., the Hsp90mRNA expression was respectively 3 and 5 times higher, then ( $72 \mathrm{~h}$ and 1 week p.i.) the expression lowered to control levels of the untreated specimens. In cortisol-treated fishes, at $3 \mathrm{~h}$ and $24 \mathrm{~h}$ p.i., the Hsp90 mRNA expression was $9(P<0.001)$ and $8(P<0.001)$ times higher than untreated ones. Then ( $72 \mathrm{~h}$ and 1 week p.i.) the mRNA lowered to control levels. Differences between sham and cortisoltreated fishes were significant at $3 \mathrm{~h}(P<0.01)$ and $24 \mathrm{~h}$ $(P<0.05)$ p.i.

To assess the Hsp70 protein production, assays were performed by densitometry analysis of the immunoblotted bands. Fig. 2 shows that, in samples from groups I and II, the specific anti-mouse Hsp70 (Fig 2C) and Hsp 90 mAbs (Fig 2D) identified only $70 \mathrm{kDa}$ and $90 \mathrm{kDa}$ proteins, respectively. The densitometry profile (Fig. 2E) disclosed that the Hsp70 density was modulated in sham and cortisol-treated specimens, meanwhile no changes were observed in samples from the untreated ones. In sham fish, the band density values increased slightly at $3 \mathrm{~h}$ p.i. whereas they were higher ( 4 times, compared to the untreated fish) at $24 \mathrm{~h}$ and $72 \mathrm{~h}$ p.i. and at 1 week ( 2 times). In samples from cortisol-treated fish, the highest protein level (10 times higher) was found at $3 \mathrm{~h}$ p.i.; then it lowered at $24 \mathrm{~h}$ ( 8 times higher), $72 \mathrm{~h}$ and 1 week ( 5 times higher). Differences between sham and cortisol-treated specimens were significant $(P<0.01)$ at $3 \mathrm{~h}$ and $24 \mathrm{~h}$ p.i., only.

In samples from the cortisol-treated fish, the densitometry highlights a significant change in Hsp90 density at $24 \mathrm{~h}$ and $72 \mathrm{~h}$ p.i. (Fig. 2F), whereas in samples from sham fish the protein density was almost constant and equal to the controls. In particular, the density was 7 and 13 times higher at $24 \mathrm{~h}$ and $72 \mathrm{~h}$ (respectively) after the cortisol injection $(P<0.05$ and $P<0.001)$. Such a difference was also found by comparing samples from sham and cortisol-treated fishes $(P<0.01)$.

\subsection{Hsp70 and Hsp90 mRNA expression and protein levels after cortisol in vitro treatment of head kidney cells}

Cell populations from the head kidney include erythrocytes and leukocytes, while only leukocytes were contained in the Percoll separated populations.

The analysis of total head kidney cells treated for $3 \mathrm{~h}$ with cortisol at various concentrations $(10,100,1000,10,000 \mathrm{ng} / \mathrm{ml})$ and compared to the untreated samples, showed no significant effect of $10-1000 \mathrm{ng} / \mathrm{ml}$ cortisol on the Hsp70 mRNA expression (Fig. 3A). Similarly, the Hsp70mRNA of isolated leukocytes remains at a constant level up to $1000 \mathrm{ng} / \mathrm{ml}$ cortisol, whereas only $10000 \mathrm{ng} / \mathrm{ml}$ cortisol lowered the mRNA in total cells and isolated leukocytes $(P<0.01)$ (Fig. 3A).

Also the levels of Hsp90 mRNA from total and isolated cells did not change significantly (Fig. 3B). Only the treatment of isolated leukocytes with the highest cortisol concentration, compared to the medium-treated cells, significantly $(P<0.01)$ decreased (about $30 \%)$ the Hsp90 mRNA expression. Fig. $3 \mathrm{C} 1$ and $\mathrm{C} 2$ shows that the anti-mouse Hsp70 mAbs cross-reacted with a $70 \mathrm{kDa}$ band of the head kidney total cells, whereas it could be identified in the iso- lated leukocytes samples only after the cells were treated with $10,000 \mathrm{ng} / \mathrm{ml}$ cortisol (Fig. 3C2). As shown in Fig. 3, the anti-mouse Hsp90 mAbs cross-reacted with a $90 \mathrm{kDa}$ band present both in total cells (Fig. 3D1) and isolated leukocytes preparations (Fig. 3D2). Densitometry analysis of Hsp70 protein (Fig. 3E) shows a constant and significant increase in total cells samples. In particular, the density reached the highest level ( 6 times higher than the untreated samples) after a treatment with $10,000 \mathrm{ng} / \mathrm{ml}$ cortisol. The Hsp70 band density revealed after $10,000 \mathrm{ng} / \mathrm{ml}$ cortisol treatment of the isolated leukocytes was 10 times higher $(P<0.001)$ than that observed in the untreated samples. The $90 \mathrm{kDa}$ band identified in the total cell lysate did not indicate any significant density change following cortisol treatments (from 10 up to $10,000 \mathrm{ng} / \mathrm{ml}$ ) (Fig. 3F) and a constant value (up to $1000 \mathrm{ng} / \mathrm{ml}$ cortisol) was found. On the contrary, when isolated leukocytes were treated with $10,000 \mathrm{ng} / \mathrm{ml}$ cortisol, the protein density underwent a significant $(P<0.05)$ increase (Fig. $3 F)$.

\subsection{Cortisol treated cells were not apoptotic}

Head kidney cells (total and isolated) were viable after $3 \mathrm{~h}$ culture in cortisol-free medium. Although cell viability, revealed by MTT assay, slightly decreased in a dose-dependent fashion, Fig. 4A shows that increasing cortisol concentrations (up to $10,000 \mathrm{ng} / \mathrm{ml}$ ) did not significantly change viability. A diminished viability (about 10-15\% less) was only found at the highest cortisol concentration $(10000 \mathrm{ng} / \mathrm{ml})$, overcoming the expected effect of this hormone.

In agarose gel, DNA electrophoresis pattern of the unseparated cells did not show any typical feature of apoptotic DNA ladders (Fig. 4B).

\section{Discussion}

In fish, the Y shaped kidney placed along the body axis is composed with a lower part that works as a renal system, and two arms (aglomerular head kidney or pronephrous) that perform hemopoietic and immune functions, i.e., phagocytosis, antigen processing, development of B lymphocytes, macrophages and granulocytes, production of IgM-like immunoglobulins, and immune memory $[39,32,50]$. The head kidney also is an important endocrine organ, homologous to mammalian adrenal glands, that releases cortisol produced by the interrenal tissue [18] and is considered the central organ for immune-endocrine interactions $[37,39]$. There is increasing evidence that cortisol may have a direct influence on the cellular stress response [6] including the possible interplay between cortisol and Hsps [36] that modulates several functions including both adaptive and innate immune responses [48]. Numerous studies have been focused on the effects of cortisol administration, both in vitro and in vivo, revealing the hormone immunomodulatory effects [39] that can be mediated via GRs already identified in fish leukocytes including seabass $[39,44]$.

Our results show that in sea bass, following cortisol intraperitoneal injection or in vitro treatment of head kidney cells, a high cortisol level exerts modulating activity on the Hsps expression. To highlight the in vivo response, the cortisol-treated fishes were compared not only with untreated specimens but also with those injected with the vehicle (sham fish) i.e., the medium used to dissolve the hormone. The sea bass plasma cortisol baseline appeared to be higher than previously reported (at $10 \pm 8 \mathrm{ng} / \mathrm{ml}$ in reference [40]), however different environmental conditions and population density as well as fish drawing out from different farms could account for the difference. The exogenous cortisol circulated in the blood and mimicked stress conditions (mainly at 3 and $24 \mathrm{~h}$ p.i.) 

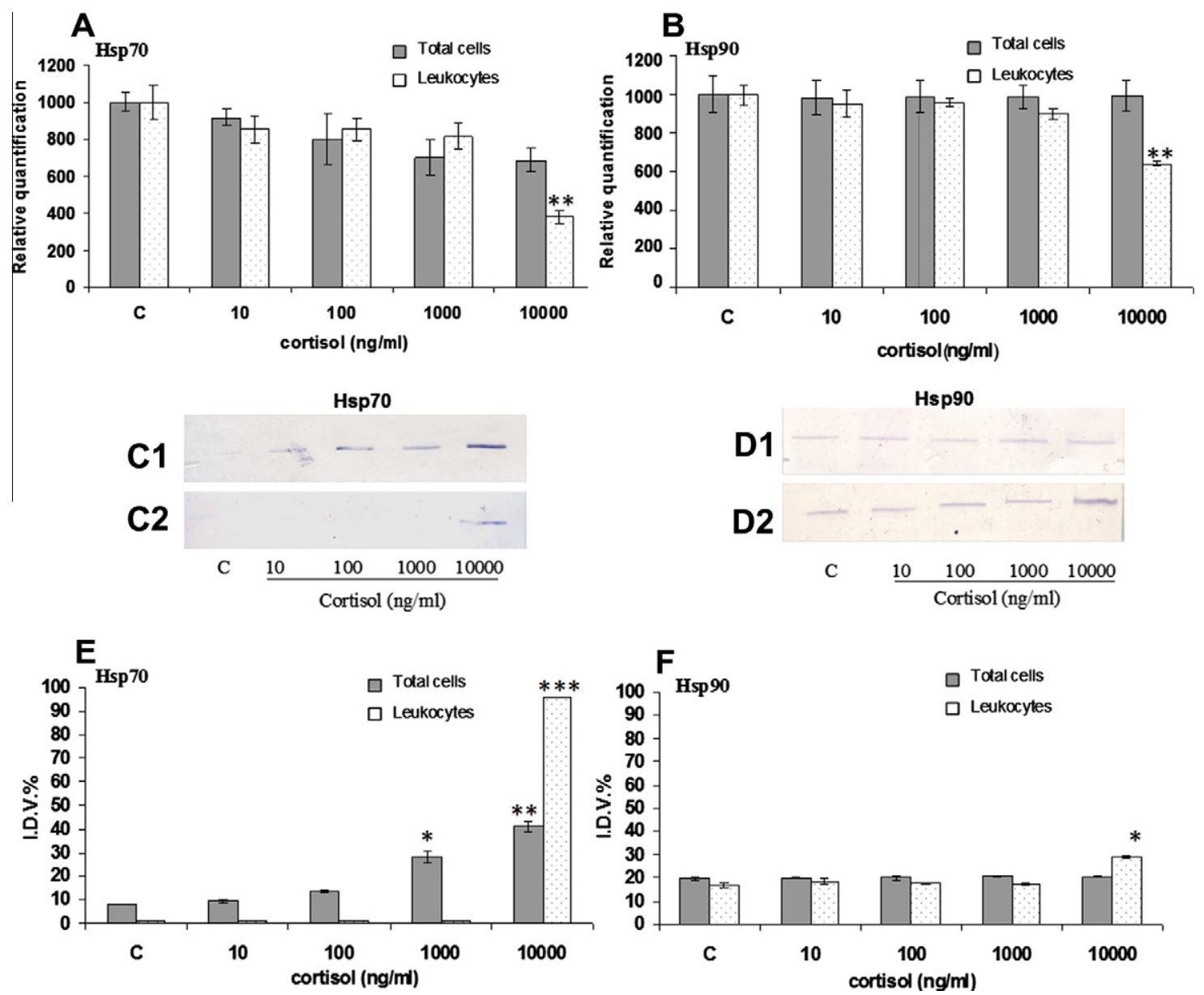

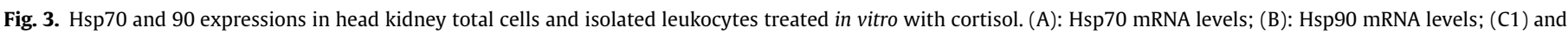

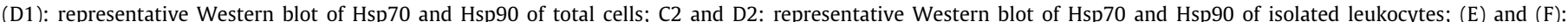

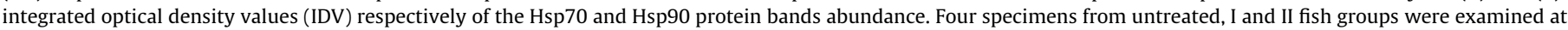

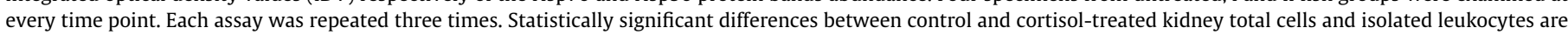
shown upon the bars $\left({ }^{*} P<0.05,{ }^{* *} P<0.01,{ }^{* * *} P<0.001\right)$.

as suggested by increased values of serological parameters (glucose, lactate, and osmolarity).

Real-time PCR analysis of the tissue from sham and cortisoltreated specimens clearly showed that, despite the enhanced plasma cortisol level, the Hsp70 mRNA expression was at a baseline value. A significant increase both in sham and cortisol-treated specimens was found at $72 \mathrm{~h}$ p.i., just when the cortisol level decreased, suggesting a delayed genomic modulation. Assays at intermediate time-points could establish the precise lowering-time. Although a decrease was observed at 1 week p.i., a high Hsp70 mRNA level was still observed indicating a prolonged gene activity after circulating cortisol started the response. It should be emphasized that, after cortisol administration, the Hsp70 and cortisol levels ( $3 \mathrm{~h}$ and $24 \mathrm{~h}$ sampling) were always significantly higher than those recorded in sham fish. An opposite trend characterized the Hsp70 protein identified by an immunoblotting method with anti-mouse Hsp70 mAbs. A single $70 \mathrm{kDa}$ band was detected in the head kidney lysate supernatant, and densitometry analysis showed that the band density time-course approximately overlapped the dynamic of plasma cortisol. The protein reached the highest value at $3 \mathrm{~h}$, then $(24 \mathrm{~h})$, although still high, decreased up to the non significant value found at $72 \mathrm{~h}$ just when the Hsp70 mRNA increased. A different behavior characterized the Hsp90 gene expression that was mainly upregulated at $3 \mathrm{~h}$ and $24 \mathrm{~h}$ reaching the base-line value at 1 week. The Hsp70 and Hsp90 genes upregulation may be related to the circulating cortisol suggesting a cortisol-dependent gene activation that could be arranged in order of occurrence. In this respect, the optical density of the immunoblotted Hsp90 protein detected by the anti-mouse inducible Hsp90 mAbs, suggests an inverse ratio (at $72 \mathrm{~h}$ p.i.). It is notable that, in the head kidney, the Hsp70 and Hsp90 appear to be inducible.

Since inducible Hsp expression in all organisms can be regulated by the heat shock transcription factors (HSFs), our results suggest that high Hsp protein level blocks the transcription. Several HSFs have been cloned and characterized in fish $[34,46,28]$. In all vertebrates, stress does not alter the quantity of HSF produced, but its activity is regulated on a post-transcriptional level through oligomerization, translocation and hyperphosphorylation [9], providing a mean of differential control of transcription. During stressful conditions, pre-formed Hsp70 and Hsp90 dissociated from HSF [26], move into the nucleus where activated gene transcription takes place [30]. In sea bass, the opposite trend between Hsp70 mRNA expression and amount of produced protein, suggests that after circulating cortisol was enhanced, the translation of pre-existing or just produced mRNA, blocks gene activation [23]. On the contrary, Hsp90 gene was upregulated by cortisol and then downregulated through the synthesized protein. In both cases a negative feedback mechanism could be invoked [45]. In other fish species, similar results have been reported $[29,35]$ and 


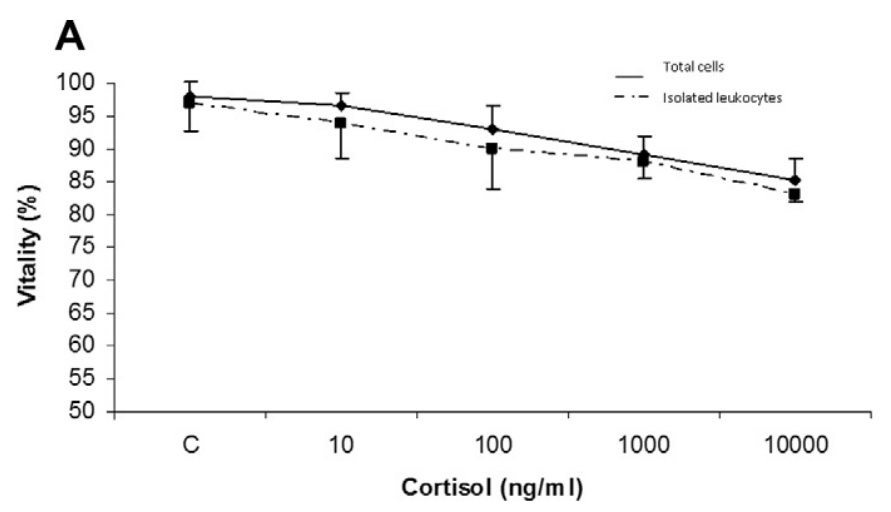

\section{B}

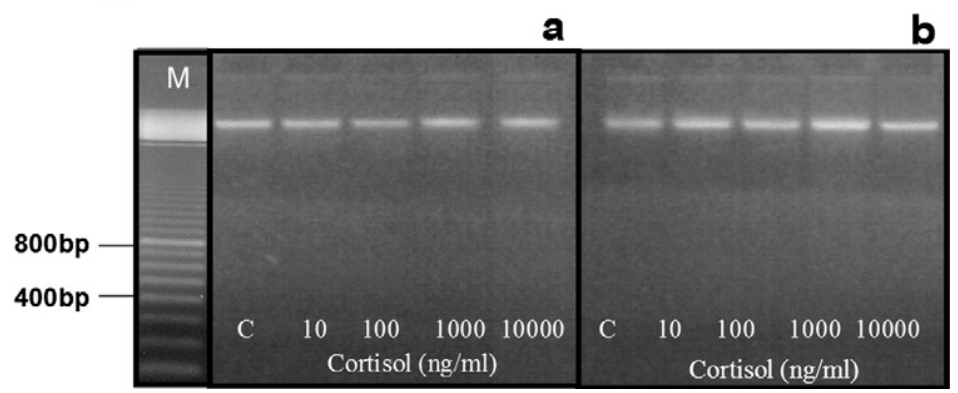

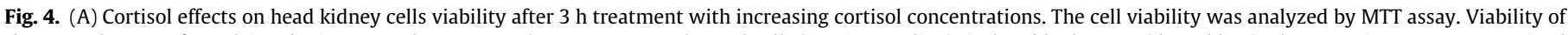

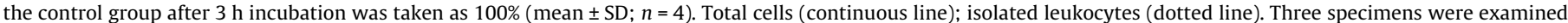

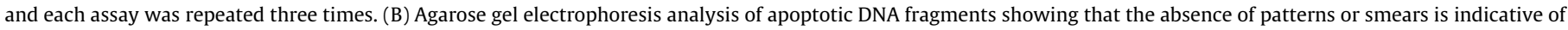

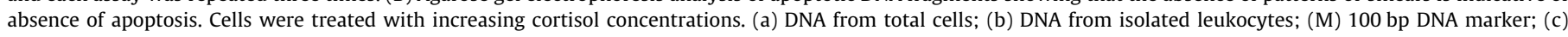
control. Three specimens were examined and each assay was repeated three times.

it has been shown a quick time (15-90 min) for Hsp70 mRNA transcription [17] Differences in cortisol Hsp modulation reported in the literature $[1,12,43]$ could be dependent on the organ and cell types examined in various fish species and/or by the experimental conditions. Since in seabass head kidney two distinct GRs (DIGR1 and DIGR2) $[41,38]$ are differently modulated by exogeneous cortisol [42], being DIGR1 upregulated, the possibility exists that the latter is involved in cortisol modulation of Hsps [42].

To check for the relationships between cortisol-modulated Hsps and head kidney leukocytes response, the cortisol effects were examined after $3 \mathrm{~h}$ incubation of total cells or isolated leukocytes with increasing hormone doses (10-100-1000-10,000 ng/ml). Both cell preparations presented Hsp70 mRNA expression that diminished inversely to the dose showing a significant $(P<0.01)$ decrease at the pharmacological dose $(10,000 \mathrm{ng} / \mathrm{ml})[14,22]$ just when the protein level significantly increased (densitometry data). Although the protein bands were feeble, the profile of Hsp70 protein density revealed an evident dose-dependent increase inversely proportional to the mRNA levels, whereas the cell Hsp90level remained almost unchanged up to $1000 \mathrm{ng} / \mathrm{ml}$ concentration. In this respect it is known that the Hsp70 is involved in numerous stress-dependent cell mechanisms whereas more specific and limited intervention have been imputed to the Hsp90 [8,35,31]. This is also supported by the highest Hsp70 production in vitro though at the cortisol pharmacological dose. The Hsp genes expression and protein density modulation were more evident in isolated leukocyte preparations which were deprived of erythrocytes which could affect the Hsps estimation. The treatments demonstrated that these cells were responsive to cortisol, they expressed mRNA and produced inducible Hsps. These findings are consistent with the in vitro cortisol effects on seabass peritoneal cavity leukocyte activity [44], namely modulation of oxygen reactive intermediates production usually associated to phagocyte activity. In spite of the cortisol treatment that could cause apoptosis [13,11], no apoptotic effects were found in the cells that conversely presented high vitality levels (MTT) and did not show any DNA fragmentation. This finding may be related to the Hsp70 anti-apoptotic effect [13].

In conclusion, since fishes are constantly exposed to stressful conditions they have evolved neuroendocrine responses including cortisol production that modulates the expression of the head kidney inducible Hsps. In addition, according to Iwama et al. [20], the possibility exists that Hsp70 and 90 levels can vary in a same organ, in various tissues and species making their use, as stress indicators, a complex issue.

\section{References}

[1] P. Ackerman, A.R. Forsyth, C.F. Mazur, G.K. Iwama, Stress hormones and the cellular stress response in salmonids, Fish Physiol. Biochem. 23 (2000) 327336.

[2] R. Aneja, K. Odoms, K. Dunsmore, T.P. Shanley, H.R. Wong, Extracellular heat shock protein-70 induces endotoxin tolerance in THP-1 cells, J. Immunol. 177 (2006) 7184-7192.

[3] B.A. Barton, J.D. Morgan, M.M. Vijayan, Physiological and condition-related indicators of environmental stress in fish, in: S.M. Adams (Ed.), Biological Indicators of Aquatic Ecosystem Stress, American Fisheries Society, Bethesda, USA, 2002, pp. 111-148.

[4] N. Basu, T. Nakano, E.G. Grau, G.K. Iwama, The effects of cortisol on heat shock protein 70 levels in two fish species, Gen. Comp. Endocrinol. 124 (2001) 97105.

[5] N. Basu, A.E. Todgham, P.A. Ackerman, M.R. Bibeau, K. Nakano, P.M. Schulte, G.K. Iwama, Heat shock protein genes and their functional significance in fish, Gene 295 (2002) 173-183.

[6] A.M. Boone, M.M. Vijayan, Glucocorticoid mediated attenuation of the HSP70 response in trout hepatocytes involves the proteasome, Am. J. Physiol. 283 (2002) R680-R687.

[7] M.M. Bradford, A rapid and sensitive method for the quantitation of microgram quantities of proteins utilizing the principles of protein-dye binding, Anal. Biochem. 72 (1976) 248-254.

[8] J.B. Cara, N. Alum, F.J. Moyano, M.M. Vijayan, Food-deprivation induces HSP70 and HSP90 protein expression in larval gilthead sea bream and rainbow trout, Comp. Biochem. Physiol. 142 (2005) 426-431. 
[9] J. Cotto, M. Kline, R.I. Morimoto, Activation of heat shock factor 1 DNA binding precedes stress-induced serine phosphorylation, J. Biol. Chem. 271 (1996) 3355-3358.

[10] S. Currie, B. Tufts, Synthesis of stress protein $70 \mathrm{Hsp} 70$, in rainbow trout Oncorhynchus mykiss, red blood cells, J. Exp. Biol. 200 (1997) 607-614.

[11] E.E. Deane, N.Y.S. Woo, Cloning and characterization of the HSP70 multigene family from silver sea bream: modulated gene expression between warm and cold temperature acclimation, Biochem. Biophys. Res. Commun. 330 (2005) 776-783.

[12] E.E. Deane, S.P. Kelly, C.K.M. Lo, N.Y.S. Woo, Effect of GH, prolactin and cortisol on hepatic HSP70 expression in a marine teleost Sparus sarba, J. Endocrinol 161 (1999) 413-421.

[13] E.E. Deane, L. Zhou, N.Y.S. Woo, Cortisol can be pro- or anti-apoptotic in sea bream cells: Potential role of HSP70 induction for cytoprotection, Mol. Cell. Endocrinol. 259 (2006) 57-64.

[14] M.A. Esteban, A. Rodríguez, A.G. Ayala, J. Meseguer, Effects of high doses of cortisol on innate cellular immune response of seabream (Sparus aurata L.), Gen. Comp. Endocrinol. 137 (2004) 89-98.

[15] M.E. Feder, G.E. Hofmann, Heat shock proteins, molecular chaperones, and the stress response: evolutionary and ecological physiology, Annu. Rev. Physiol. (1999) 234-282.

[16] A.L. Fink, in: A.L. Fink, Y. Goto (Eds.), Molecular Chaperones in the Life Cycle of Proteins: Structure, Function and Mode of Action, Marcel Dekker, New York, 1998, pp. 123-150.

[17] R. Gornati, E. Papis, S. Rimoldi, G. Terova, M. Saroglia, G. Bernardini, Rearing density influences the expression of stress related genes in seabass (Dicentrarchus labrax, L.), Gene 341 (2004) 111-118.

[18] J. Harris, J.D. Bird, Modulation of the fish immune system by hormones, Vet. Immunol. Immunopathol. 77 (2000) 163-176.

[19] G.K. Iwama, P.T. Thomas, R.B. Forsyth, M.M. Vijayan, Heat-shock protein expression in fish, Rev. Fish. Biol. Fish. 8 (1998) 35-56.

[20] G.K. Iwama, L.O.B. Afonso, A. Todgham, P. Ackerman, K. Nakano, Are hsps suitable for indicating stressed states in fish?, J Exp. Biol. 207 (2004) 15-19.

[21] U.K. Laemmli, Cleavage of structural proteins during the assembly of the head of bacteriophage T4, Nature 227 (1970) 680-685.

[22] W.Y. Law, W.H. Chen, Y.L. Song, S. Dufour, C.F. Chang, Differential in vitro suppressive effects of steroids on leukocyte phagocytosis in two teleosts, tilapia and common carp, Gen. Comp. Endocrinol. 121 (2001) 163-172.

[23] S. Lindquist, The heat-shock response, Annu. Rev. Biochem. 55 (1986) 1151 1191.

[24] G. Maricchiolo, S. Mirto, G. Caruso, T. Caruso, R. Bonaventura, M. Celi, V. Matranga, L. Genovese, Welfare status of cage farmed European sea bass (Dicentrarchus labrax): a comparison between submerged and surface cages, Aquaculture 314 (2011) 173-181.

[25] T.P. Mommsen, M.M. Vijayan, T.W. Moon, Cortisol in teleosts: dynamics, mechanisms of action, and metabolic regulation, Rev. Fish. Biol. Fish. 8 (1999) 211-268.

[26] R.I. Morimoto, M.P. Kline, D.N. Bimston, J.J. Cotto, The heatshock response: regulation and function of heat-shock proteins and molecular chaperones, Essays Biochem. 32 (1997) 17-29.

[27] T. Mosmann, Rapid colorimetric assay for cellular growth and survival: application to proliferation and cytotoxicity assays, J. Immunol. Methods 65 (1983) 55-63.

[28] N. Ojima, M. Yamashita, Cloning and characterization of two distinct isoforms of rainbow trout heat shock factor 1, Eur. J. Biochem. 271 (2004) 703-712.

[29] N. Ojima, M. Yamashita, S. Watabe, Quantitative mRNA expression profiling of heat-shock protein families in rainbow trout cells, Biochem. Biophys. Res. Commun. 329 (2005) 51-57.

[30] J. Park, A.Y. Liu, JNK phosphorylates the HSF1 transcriptional activation domain: role of JNK in the regulation of the heat shock response, J. Cell. Biochem. 82 (2001) 326-338.
[31] C. Poltronieri, L. Macatrozzo, C. Simontacchi, D. Bernotto, M. Patruno, G. Radaelli, Quantitative RT-PCR analysis and immunohistochemical localization of HSP70 in sea bass Dicentrarchus labrax exposed to transport stress, Eur. J. Histochem. 51 (2007) 125-136.

[32] C.McL. Press, Ø. Evensen, The morphology of the immune system in teleost fishes, Fish Shell. Immunol. 9 (1999) 309-318.

[33] P. Prunet, A. Sturm, S. Milla, Multiple corticosteroid receptors in fish: from old ideas to new concepts, Gen. Comp. Endocrinol. 147 (2006) 17-23.

[34] C.M. Råbergh, S. Airaksinen, A. Soitamo, H.V. Bjorklund, T. Johansson, M. Nikinmaa, L. Sistonen, Tissue-specific expression of zebrafish (Danio rerio) heat shock factor 1 mRNAs in response to heat stress, J. Exp. Biol. 203 (2000) 18171824.

[35] R. Sathiyaa, M.M. Vijayan, Autoregulation of glucocorticoid receptor by cortisol in rainbow trout hepatocytes, Cell Physiol. 284 (2003) C1508-C1515.

[36] R. Sathiyaa, T. Campbell, M.M. Vijayan, Cortisol modulates hsp90 mRNA expression in primary cultures of trout hepatocytes, Comp. Biochem. Physiol. 129 (2001) 679-685.

[37] J.W. Stave, B.S. Roberson, F.M. Hetrick, Chemiluminescence of phagocytic cells isolated from the pronefros of stiped bass, Dev. Comp. Immunol. 7 (1983) 269276.

[38] G. Terova, R. Gornati, S. Rimordi, G. Bernardini, M. Saroglia, Quantification of a glucocorticoid receptor in sea bass (Dicentrarchus labrax, L.) reared at hight stocking density, Gene 357 (2005) 144-151.

[39] L. Tort, J.C. Balasch, S. Mackenzie, Fish immune system. A crossroads between innate and adaptive responses, Immunología 22 (2003) 277-286.

[40] M. Vazzana, M. Cammarata, E.L. Cooper, N. Parrinello, Confinement stress in sea bass (Dicentrarchus labrax) depresses peritoneal leukocyte cytotoxicity, Aquaculture 210 (2002) 231-243.

[41] M. Vazzana, A. Vizzini, G. Salerno, M.L. Di Bella, M. Celi, N. Parrinello, Expression of a glucocorticoid receptor (DlGR1) in several tissues of the teleost fish Dicentrarchus labrax, Tissue Cell 40 (2008) 89-94.

[42] M. Vazzana, A. Vizzini, M.A. Sanfratello, M. Celi, G. Salerno, N. Parrinello, Differential expression of two glucocorticoid receptors in seabass (teleost fish) head kidney after exogeneous cortisol inoculation, Comp. Biochem. Physiol. 157 (2010) 49-54.

[43] M.M. Vijayan, S. Raptis, R. Sathiyaa, Cortisol treatment affects glucocorticoid receptor and glucocorticoid-responsive genes in the liver of rainbow trout, Gen. Comp. Endocrinol. 132 (2003) 256-263.

[44] A. Vizzini, M. Vazzana, M. Cammarata, N. Parrinello, Peritoneal cavity phagocytes from the teleost sea bass express a glucocorticoid receptor (cloned and sequenced) involved in genomic modulation of the in vitro chemiluminescence response to zymosan, Gen. Comp. Endocrinol. 150 (2007) 114-123.

[45] S.A. Wadekar, D. Li, S. Periyasamy, E.R. Sánchez, Inhibition of heat shock transcription factor by GR, Mol. Endocrinol. 15 (2001) 1396-1410.

[46] J. Wang, Y. Wei, X. Li, H. Cao, M. Xu, J. Dai, The identification of heat shock protein genes in goldfish (Carassius auratus) and their expression in a complex environment in Gaobeidian Lake, Beijing, China, Comp. Biochem. Physiol. (2007) 350-362.

[47] S.E. Wendelaar Bonga, The stress response in fish, Physiol. Rev. 77 (1997). 59162.

[48] L. Whitesell, P. Cook, Stable and specific binding of heat shock protein 90 by geldanamycin disrupts glucocorticoid receptor function in intact cells, Mol. Endocrinol. 10 (1996) 705-712.

[49] M. Yamashita, K. Hirayoshi, K. Nakata, Characterization of multiple members of the hsp70 family in platyfish culture cells: molecular evolution of stress protein hsp70 in vertebrates, Gene 336 (2004) 207-218.

[50] A. Zapata, A. Chibá, A. Varas, Cell and tissue of the immune system of fish, in: G. Iwama, T. Nakanishi (Eds.), The Fish Immune System: Organism, Pathogen and Environment, Academic Press, San Diego, 1996, pp. 255-287. 